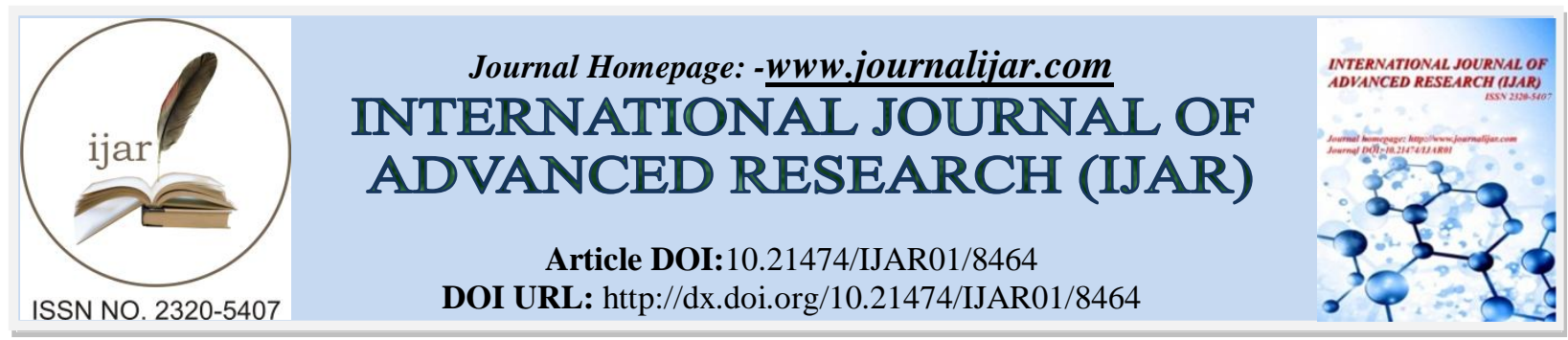

RESEARCH ARTICLE

\title{
FOOD SAFETY KNOWLEDGE, ATTITUDES AND PRACTICES OF DAIRY PRODUCTS HANDLERS IN DAIRIES OF OUAGADOUGOU, BURKINA FASO.
}

\section{Aissaioulè Pauline Millogo-Dah ${ }^{1}$, Abel Tankoano ${ }^{1}$, Abdou Azize Wendketa Ouédraogo ${ }^{3}$, Hagrétou Sawadogo- Lingani $^{2}$ and Aly Savadogo ${ }^{1}$.}

1. Laboratoire de Biochimie et d'Immunologie Appliquées, Department of Biochemistry-Microbiology Université Ouaga 1 Pr Joseph KI-ZERBO Burkina Faso 03 BP 7021 Ouagadougou 03 Burkina Faso.

2. Institut de Recherche en Sciences Appliquées et Technologies Département Technologie Alimentaire 03 BP 7047 Ouagadougou 03 Burkina Faso.

3. Laboratoire National de Santé Publique 09 BP 24 Ouagadougou 09 Burkina Faso.

\section{Manuscript Info}

\section{Manuscript History}

Received: 02 December 2018

Final Accepted: 04 January 2019

Published: February 2019

\section{Key words:-}

Food safety, food handlers, knowledge, attitudes, practices, Ouagadougou.

\section{Abstract}

This cross sectional study was conducted to determine the level of knowledge, attitude and practices of dairy products handlers in twentyseven dairies in Ouagadougou, regarding food safety. Data were collected from 80 handler's trough questionnaire from April 2018 to June 2018.

Responses on food safety knowledge (i.e. foodborne diseases, symptoms and pathogens, personal hygiene, good handling practices, time and temperature, cross contamination), attitude and practices were scored to determine the level of handlers. Compiled data were analyzed by using the Statistical Packages for Social Science (SPSS) 16.0. The results showed that there was significantly positive correlation among the three levels and globally, respondents possess insufficient food safety knowledge scores $(55.28 \pm 10.28)$ and practices $(27.03 \pm 5.7)$. Attitudes were positive with score of $24.48 \pm 4.15$. Majority of respondents were female $(68.8 \%)$, under 35 years $(67.6 \%)$, without formal education or have only primary level. Dairy products handlers were aware of the importance of personal hygiene and good handling practices with regards to the prevention of foodborne diseases. However, some other aspects were of concern. Handlers did not know most of pathogens responsible of foodborne diseases, symptoms, time and temperature control and cross contamination. They also had insufficient practices included lack of health check, using uniform and cape, soap and sanitizer during washing hands. The study's findings highlighted issues with regards to the extent of knowledge acquisition by dairy products handlers. Therefore, trainings must be adequate, i.e. on-site, in local language and based on risk management.

Copy Right, IJAR, 2019,. All rights reserved.

Corresponding Author:-Aissaioulè Pauline Millogo-Dah.

Address:-Laboratoire de Biochimieetd'ImmunologieAppliquées, Department of BiochemistryMicrobiology UniversitéOuaga 1 Pr Joseph KI-ZERBO Burkina Faso 03 BP 7021 Ouagadougou 03 Burkina Faso. 


\section{Introduction:-}

Foodborne diseases and outbreaks are crucial contributors to morbidity and mortality worldwide (Flint et al., 2005). According to World Health Organization (WHO), every year, more than one-third of the total population in developing countries are affected by foodborne diseases (OMS, 2007). Food safety is more and more an important public health concern (OMS, 2014). In developing countries where production of milk and milk products take place under unsanitary conditions and poor practices, the safety of dairy products with respect to foodborne diseases is of great issue (Sahingoz et al., 2009). Several studies found that dairy products consumption were growing in urban area in Burkina Faso (Dah et al., 2018; Tankoano, 2014; Broutin, 2002). Strong demand entails a deep increase in formal and informal dairies. Dairy products from these dairies are subjected to a lot of contamination (Belli et al., 2013; Jørgensen et al., 2005; Grana et al., 2003). Among these contaminants, there are microorganisms such as Staphyloccocusaureus, Bacillus sp., Escherichia coli, Salmonella sp., Yersinia sp., Campylobacter sp., yeasts and casts, physical and chemical (toxins and antibiotics residues) contaminants (Bagré, 2015). According to Campos et al. (2009) food handlers play a major reason in contaminating food. Indeed, human handling errors have been responsible for most outbreaks of food poisoning (Greig et al., 2007; Clayton et al., 2002), during preparation, processing or storage (Mederios et al., 2001). Three factors are playing fundamental role in food poisoning outbreaks concerning food handlers: knowledge, attitude and practice (Sharif and Al-Malki, 2010). Bas et al. (2006) have suggested the KAP approach: as knowledge $(\mathrm{K})$ is believed to be the precursor that influences an individual's practice $(\mathrm{P})$ and the information will lead to a change in attitude (A) and consequently a change in behaviour. Such information is important in designing training modules and targeted mitigation strategies to advance food safety for food handlers. Many studies about the knowledge, attitude and practices of food handlers have been conducted worldwide (Kunadu et al., 2016; Farahat, et al., 2015; Annor and Baiden, 2011; Toku et al., 2008; Jevšnik et al., 2008; Gomes-Neves et al., 2007; Bas et al., 2006). However, in Burkina Faso, no study has been carried out to evaluate food safety knowledge, attitudes and practices of food handlers in dairies, although this sector.

This research aims to investigate the level of food safety knowledge, attitudes and practices of food handlers in dairies in Ouagadougou, and to elucidate the relationship among different food handler characteristics. The result of this survey can improve the efficacy of training materials, and generate baseline data for evidence-based improvements which will enable dairy business operators to implement and maintain effective food safety management systems.

\section{Material and Methods:-}

\section{Research population and data collection}

This transversal study was conducted among 30 dairies in Ouagadougou from April 2018 until June 2018. The dairies were visited during their normal operating hours. A total of 80 food handlers and data were collected through questionnaire filling and direct observation to examine knowledge, attitudes and practices. The respondents were given sufficient time ( $\sim 30 \mathrm{~min})$ to fill the questionnaire.

\section{Survey instrument}

A cross-sectional questionnaire was designed to conduct the survey. The language of questionnaire was translated to the local languages "mooré" and "dioula" of the participants and translate back to English for publication. The questionnaire and the interview procedures were pre-tested in a selected dairies outside the research area, to confirm question clarity, identify response options and estimate likely interview duration. The questionnaire was validated on 10 food handlers and it was then revised and the final version were divided into four distinct parts inspired from previous literature reviews with some modifications:

1. part I was used to collect data on respondent's sex, age, level of education, first language, work experience, field of duty, and length of employment in current dairy profession and whether the respondent participated in any food safety training;

2. part II (knowledge section) included 51 questions that tested respondents on their knowledge of foodborne diseases, their personal hygiene, good manufacturing practices, time and temperature control and cross contamination. Each question consisted of three optional answers of "true", "false" and "do not know".

3. sixteen questions in part III were designed to assess attitudes of respondents in terms of safe food handling.

4. part IV contained 21 questions, focused on the respondent's practice during food handling: food safety control, personal hygiene, hand washing. 
Each correct answer in the questionnaire was giving 2 points whilst incorrect answer or I do not know answer was awarded zero point. Knowledge and practices were categorized as "insufficient" when the total score was less than $70 \%$ of the maximum possible score for those sections. The respondents were categorized as having "sufficient" knowledge or practices if their total score was greater than or equal to $70 \%$ of the maximum possible score. Attitudes were classified as "negative" if the total score was less than $70 \%$ of the maximum possible score, and "positive" if it was $\geq 70 \%$. This scoring system was adapted from a similar study (Kunadu et al., 2016, Sani and Siow, 2014). A stringent cut-off score for classification was however used in this study because the dairies offer dairy products to large populations including vulnerable groups such as sick people and children.

\section{Statistical analysis:-}

Data were analyzed using the Statistical Package for Social Sciences software, version 16.0 statistical package and in Microsoft Excel, 2013. Demographic data of all respondents were presented as frequency values and percentages. Their knowledge, attitudes and practices scores were obtained using descriptive statistics. Spearman's correlation coefficient was also used to test the association between knowledge, attitudes and practices of the respondents.

\section{Results:-}

Socio-demographic characteristics of dairy products handlers

Eighty-five percent (85\%) of dairy products handlers has worked in only one dairy up to now (Fig. 1). The maximum time spent in a dairy as an employee, frequently cited is 1 year or less $(41.3 \%)$ and 4 years (15\%) (Fig. 2).

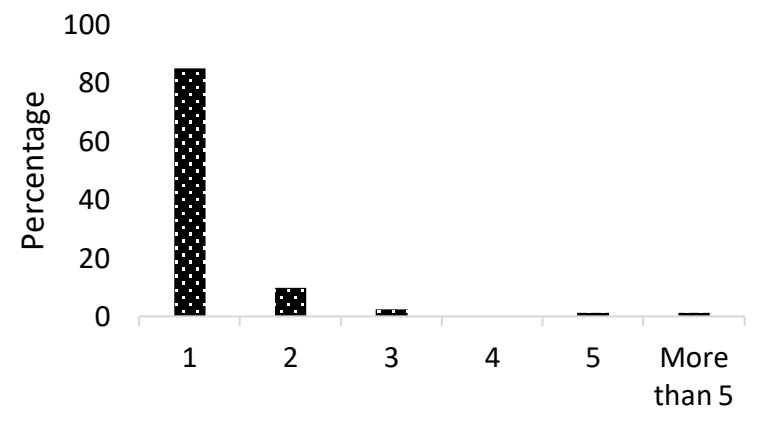

Number of dairies

Dairy products handlers (\%)

Fig 1:-Number of dairies as an employee

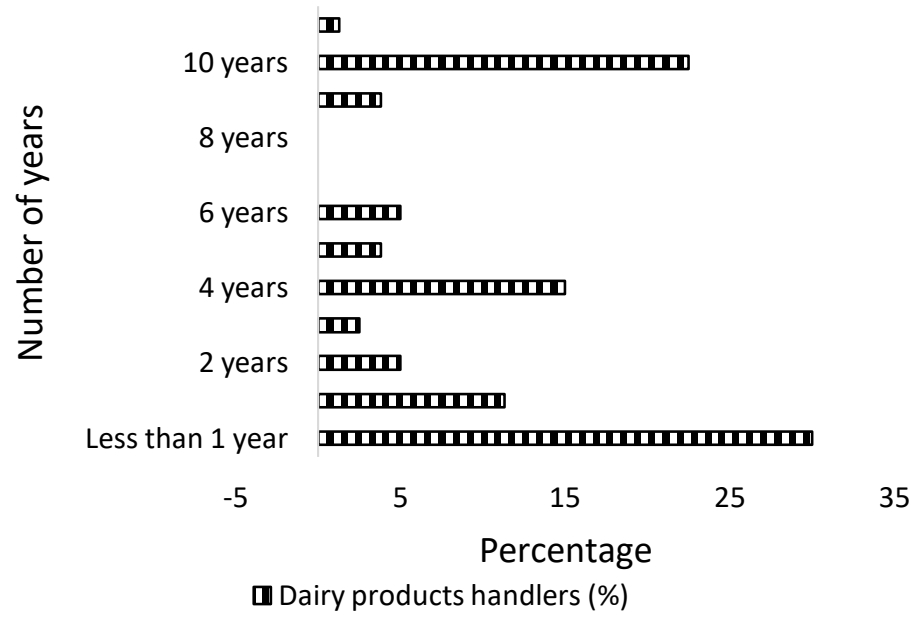

Fig 2:-The maximum time spent in a dairy as an employee 
The socio-demographic characteristics of respondents are represented in table 1 . Most of the respondents were females $(68.8 \%)$ with $67.6 \%$ aged between 15 and 35 years old. A total of $22.5 \%$ did not have formal education and about half $(48.8 \%)$ were primary school. The most frequently reported working experience were 1-5 years $(70$ $\%$ ), also around $30.1 \%$ have worked for over 6 years. It was found that majority of surveyed (81.2 \%) first language is a local language "mooré" and only $15 \%$ first language is French. Around $82.5 \%$ worked as manufacturer and $37.5 \%$ were chief of the dairy. Only $31.3 \%$ of respondents had their health cards, 38.7 attended training related to food safety while $84.4 \%$ had no training proof.

Table 1:-Demographic characteristics of the respondents

\begin{tabular}{|c|c|c|}
\hline \multicolumn{2}{|c|}{ Characteristics } & \multirow{2}{*}{$\begin{array}{c}\text { Proportion (\%) } \\
31.3 \\
\end{array}$} \\
\hline Gender & Male & \\
\hline & Female & 68.8 \\
\hline \multirow{5}{*}{ Age group } & $15-25$ & 33.8 \\
\hline & $26-35$ & 33.8 \\
\hline & $36-45$ & 26.3 \\
\hline & $46-55$ & 5 \\
\hline & $56-65$ & 1.3 \\
\hline \multirow{4}{*}{ Educational level } & No formal education & 22.5 \\
\hline & Primary & 48.8 \\
\hline & Secondary & 21.3 \\
\hline & High school & 7.5 \\
\hline \multirow{4}{*}{ Working experience } & Less than 1 year & 27.5 \\
\hline & $1-5$ years & 42.5 \\
\hline & $6-10$ years & 26.3 \\
\hline & $16-20$ years & 3.8 \\
\hline \multirow{4}{*}{ First Language } & French & 15 \\
\hline & Mooré & 81.3 \\
\hline & Dioula & 1.2 \\
\hline & Fulfuldé & 2.5 \\
\hline \multirow{3}{*}{ Field of duty } & Chief & 37.5 \\
\hline & Manufacturer & 82.5 \\
\hline & Helper & 13.8 \\
\hline \multirow{2}{*}{ Training on food safety attended } & Yes & 38.7 \\
\hline & No & 61.3 \\
\hline \multirow{5}{*}{ If yes, how many trainings on food safety } & 1 & 23.8 \\
\hline & 2 & 7.5 \\
\hline & 3 & 2.5 \\
\hline & 4 & 1.3 \\
\hline & More than 5 & 3.8 \\
\hline \multirow{3}{*}{ Training proof } & Attestation & 12.5 \\
\hline & Certificate & 3.1 \\
\hline & No proof & 84.4 \\
\hline
\end{tabular}

Food safety knowledge

Table 2 shows overall knowledge level of dairy products handlers surveyed in Ouagadougou.

Knowledge about foodborne diseases, symptoms and pathogens

About $40 \%$ of the respondents did not know that everyone is likely to become ill after ingesting an unsafe dairy product. Around the half answered incorrectly about diseases like typhoid fever, tuberculosis (70 \%). Stomach pain, fever, and diarrhea were identified as symptoms of foodborne illness by respectively $88 \%, 28 \%$ and $86.3 \%$. Less than $7 \%$ of the respondents knowing about Salmonella (5\%), Staphylococcus aureus (1.3), hepatitis A (6.3) and Escherichia coli (2.5).

\section{Knowledge about personal hygiene}

More than $80 \%$ of respondents did know that diarrhea or vomiting cases should interrupt the work immediately $(93.8 \%)$, washing hands before food handling reduce risk of contamination $(92.5 \%)$, the skin of the hands can 
house microorganisms under the nails $(82.5 \%)$, at work event if you only urinated you need to wash your hands $(88.7 \%)$, and it is not enough just by washing your hands under running water to remove bacteria before touching food $(83.7 \%)$. Only around $35 \%$ knew that wearing jewelry or having hair in the food can promote food contamination, and that it is not only forbidden to handle food in the only case where one is seriously ill.

\section{Knowledge on good handling practices}

About good handling of raw materials, ingredients and others, $53 \%$ of respondents did not know that ice can be a means of transmitting the disease. Around $80 \%$ knew that the use of an ingredient a day after the expiration date leads to health, dish towels $(81.3 \%)$ or speaking, eating or drinking while working $(78.8 \%)$ can be a source of food contamination. Almost all the respondents knew the definition of cleaning $(90 \%)$ and that food handling area must be sanitized after cleaning.

\section{Knowledge about time and temperature}

Globally, respondents knew the key role that play time and temperature in the destruction of pathogenic microorganisms in dairy products $(82.5 \%)$. Nevertheless $76.2 \%$ did not know or had a bad knowledge about some aspects of time and temperature such as the maximum time between milking and processing of raw milk in order to avoid any risk of contamination. The majority $(81.2 \%)$ gave wrong answer or did not know that dairy products are kept at a temperature below 4 degrees Celsius, refrigeration cannot kill microorganisms (61.2 \%), milk pasteurization $(62.2 \%)$, the temperature to destroy all the germs that make people sick (70\%). About $56 \%$ did not know that defrosted food cannot be refrozen.

\section{Knowledge about cross contamination}

More dairy products handlers responded correctly to questions about the risk of poorly preservation of pasteurized milk (80\%), using equipment washed the day before and rinsed with water that day to homogenized yoghurt (68.8 $\%$ ), placing in the same place in the refrigerator or freezer dairy products, raw meat and fish (56.3\%), diluting directly with running water a yoghurt if it is too condensed after pasteurization (78.8 \%). The potential sources of cross contamination recognized by respondents were raw material (66.3\%), ingredients $(41.2 \%)$, animals $(67.5 \%)$, working places and tools (90\%).

Table 2:-Food safety knowledge

\begin{tabular}{|c|c|c|}
\hline Statement & Correct responses (\%) & Mean \pm SD \\
\hline \multicolumn{3}{|l|}{ Foodborne disease, symptoms and pathogens } \\
\hline $\begin{array}{l}\text { Everyone is likely to become ill after ingesting an unsafe dairy product } \\
\text { (true) }\end{array}$ & 66.3 & $1.33 \pm 0.95$ \\
\hline Typhoid fever can be transmitted by food (true) & 55 & $1.10 \pm 1.00$ \\
\hline Malaria can be transmitted by food (false) & 61.2 & $1.23 \pm 0.98$ \\
\hline Brucellosis can be transmitted by food (true) & 12.5 & $0.25 \pm 0.66$ \\
\hline Tuberculosis can be transmitted by food (true) & 30 & $0.60 \pm 0.92$ \\
\hline Vomiting is a symptom of foodborne illness (true) & 70 & $1.40 \pm 0.92$ \\
\hline Stomach pain is a symptom of foodborne illness (true) & 88.8 & $1.78 \pm 0.64$ \\
\hline Fever is a symptom of foodborne illness (true) & 28.7 & $0.58 \pm 0.91$ \\
\hline Diarrhea is a symptom of foodborne illness (true) & 86.3 & $1.73 \pm 0.69$ \\
\hline Tiredness is a symptom of foodborne illness (true) & 20 & $0.40 \pm 0.81$ \\
\hline Head ache is a symptom of foodborne illness (true) & 17.5 & $0.35 \pm 0.76$ \\
\hline Salmonella is a foodborne pathogen (true) & 5 & $0.10 \pm 0.44$ \\
\hline Staphylococcus aureusis a foodborne pathogen (true) & 1.3 & $0.03 \pm 0.22$ \\
\hline Hepatitis A virus is a foodborne pathogen (true) & 6.3 & $0.13 \pm 0.49$ \\
\hline Hepatitis B virus is a foodborne pathogen (false) & 12.5 & $0.25 \pm 0.66$ \\
\hline Escherichia coli is a foodborne pathogen (true) & 2.5 & $0.05 \pm 0.31$ \\
\hline \multicolumn{3}{|l|}{ Personal hygiene } \\
\hline The skin of the hands can house microorganisms under the nails (true) & 82.5 & $1.65 \pm 0.76$ \\
\hline $\begin{array}{l}\text { The presence of boils, wounds or ulcers on the hands requires work } \\
\text { stoppage (true) }\end{array}$ & 68.8 & $1.38 \pm 0.93$ \\
\hline $\begin{array}{l}\text { Wearing jewellery such as earrings, rings, watches and others can } \\
\text { promote food contamination (true) }\end{array}$ & 58.8 & $1.18 \pm 0.99$ \\
\hline
\end{tabular}




\begin{tabular}{|c|c|c|}
\hline Diarrhea or vomiting cases, should interrupt the work immediately (true) & 93.8 & $1.88 \pm 0.49$ \\
\hline $\begin{array}{l}\text { It is forbidden to handle food in the only case where one is seriously ill } \\
\text { (false) }\end{array}$ & 36.3 & $0.73 \pm 0.97$ \\
\hline $\begin{array}{l}\text { Having hair in the food is unpleasant in the mouth but they are not } \\
\text { sources of contamination (false) }\end{array}$ & 40 & $0.80 \pm 0.99$ \\
\hline Informal clothes can be used as working clothes (false) & 66.3 & $1.33 \pm 0.95$ \\
\hline $\begin{array}{l}\text { At work if you only urinated, and did not have a bowel movement, you } \\
\text { do not need to wash your hands (false) }\end{array}$ & 88.7 & $1.78 \pm 0.64$ \\
\hline Washing hands before food handling reduce risk of contamination (true) & 92.5 & $1.85 \pm 0.53$ \\
\hline $\begin{array}{l}\text { It is enough just by washing your hands under running water to remove } \\
\text { bacteria before touching food (false) }\end{array}$ & 83.7 & $1.68 \pm 0.74$ \\
\hline You should dry your hands after washing (true) & 65 & $1.30 \pm 0.96$ \\
\hline \multicolumn{3}{|l|}{ Good handling practices } \\
\hline $\begin{array}{l}\text { Water can be a means of transmitting the disease, but when it is turned } \\
\text { into ice, the risk of disease transmission is reduced (false) }\end{array}$ & 46.3 & $0.93 \pm 1.00$ \\
\hline $\begin{array}{l}\text { The use of an ingredient a day after the expiration date leads to health } \\
\text { risks (true) }\end{array}$ & 72.5 & $1.45 \pm 0.90$ \\
\hline Dish towels can be a source of food contamination (true) & 81.3 & $1.63 \pm 7.79$ \\
\hline Food handling area must be sanitized after cleaning (true) & 90 & $1.80 \pm 0.60$ \\
\hline $\begin{array}{l}\text { Speaking, eating or drinking while working increase the risk of food } \\
\text { contamination (true) }\end{array}$ & 78.8 & $1.58 \pm 0.82$ \\
\hline Cleaning is to remove food or other types of soil from a surface (true) & 90 & $1.80 \pm 0.60$ \\
\hline $\begin{array}{l}\text { Sanitizing is to reduce the number of germs on a clean surface to safe } \\
\text { levels (true) }\end{array}$ & 65 & $1.30 \pm 0.96$ \\
\hline \multicolumn{3}{|l|}{ Time and temperature } \\
\hline $\begin{array}{l}\text { Time and temperature play a key role in the destruction of pathogenic } \\
\text { microorganisms in dairy products (true) }\end{array}$ & 82.5 & $1.65 \pm 0.76$ \\
\hline $\begin{array}{l}\text { Raw milk must be processed within } 4 \text { hours after milking in order to } \\
\text { avoid any risk of contamination (true) }\end{array}$ & 23.8 & $0.48 \pm 0.86$ \\
\hline Dairy products are kept at a temperature below 4 degrees Celsius (true) & 18.8 & $0.38 \pm 0.79$ \\
\hline Refrigeration kills microorganisms (false) & 38.8 & $0.78 \pm 0.98$ \\
\hline Improver food storage is dangerous to health (true) & 76.3 & $1.53 \pm 0.87$ \\
\hline Milk pasteurization $\left(45^{\circ} \mathrm{C}\right.$ for $\left.1 \mathrm{~min}\right)$ (false) & 37.5 & $0.75 \pm 0.97$ \\
\hline All the germs that make people sick are destroyed à $70^{\circ} \mathrm{C}$ (false $)$ & 30 & $0.60 \pm 0.92$ \\
\hline Defrosted food can be refrozen (false) & 43.8 & $0.88 \pm 1.00$ \\
\hline \multicolumn{3}{|l|}{ Cross contamination } \\
\hline Pasteurized milk, poorly preserved, can make people sick (true) & 80 & $1.60 \pm 0.80$ \\
\hline $\begin{array}{l}\text { The yoghurt can be homogenized using equipment washed the day } \\
\text { before and rinsed with water that day (false) }\end{array}$ & 68.8 & $1.38 \pm 0.93$ \\
\hline $\begin{array}{l}\text { Dairy products, raw meat and fish should not be placed in the same place } \\
\text { in the refrigerator or freezer (false) }\end{array}$ & 56.3 & $1.13 \pm 1.00$ \\
\hline The raw material can be a source of contamination (true) & 66.3 & $1.33 \pm 0.95$ \\
\hline Ingredients are riskless (false) & 41.2 & $0.83 \pm 0.99$ \\
\hline Animals may be in dairy products processing units (false) & 67.5 & $1.35 \pm 0.94$ \\
\hline $\begin{array}{l}\text { If a yoghurt is too condensed after pasteurization, it can be diluted } \\
\text { directly with running water (false) }\end{array}$ & 78.8 & $1.58 \pm 0.82$ \\
\hline Working places and tools may be a source of contamination (true) & 90 & $1.80 \pm 0.60$ \\
\hline Total & 56.1 & $55.28 \pm 10.28$ \\
\hline
\end{tabular}

Food safety knowledge scores

The dairy products handlers had insufficient food safety knowledge levels. Overall, the figure 3 shows that the knowledge mean score for 50 questions tested was $55.28 \pm 10.28(56.01 \%)$ with the mean score of the five aspects of food safety knowledge. 


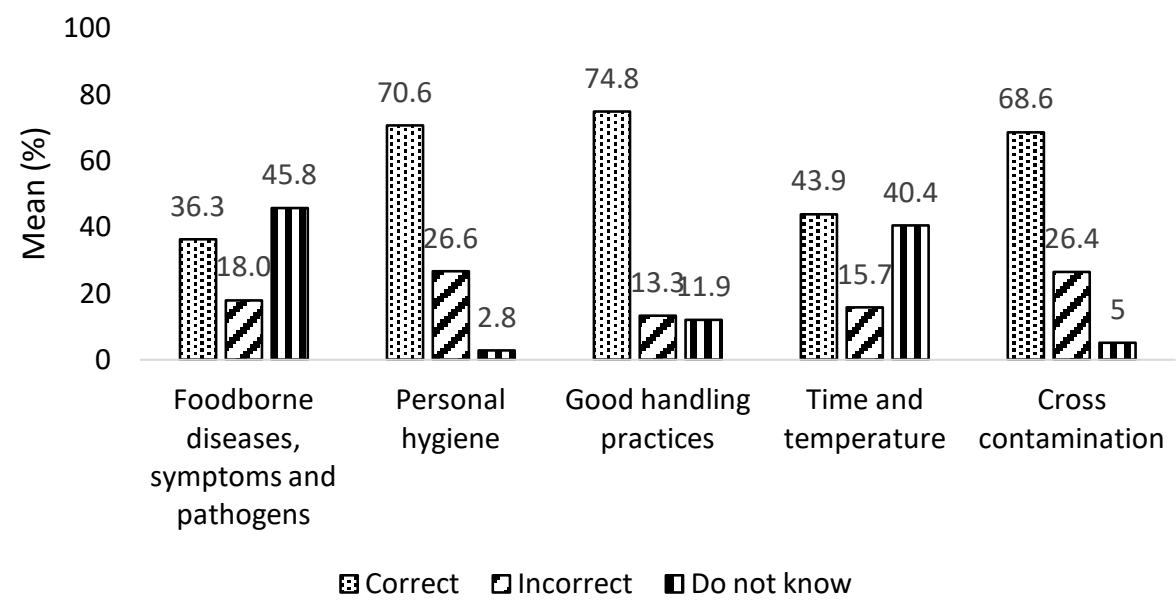

\section{Food safety practices}

Fig 3:-Mean score of food safety knowledge

Only a small group $(1.3 \%)$ of respondents went for health checks every six months (Fig. 4.). The majority practiced hand hygiene with soap before processing (67.5\%), with sanitizer $(53.8 \%$ ), after using toilet $(96.3 \%)$, and less than $10 \%$ kept long fingernail (17.5\%). $86.2 \%$ did not handle food with wounds, bruises or injuries on hands. Places in contact with dairy products are cleaning with soap before processing $(87.5 \%)$ and less than half clean the environment around the working room far from garbage; wastewater, toilets and animals. Up to $50 \%$ wore uniform while working and only $17.5 \%$ washed their working uniform every day. Around $40 \%$ wore jewelry or covered their hair while working. Certain dairy product handlers consume food or beverages inside food processing area $(27.5 \%)$ and almost the half handle objects or utensils that are not needed for processing during handling (40\%). 90 $\%$ of respondents cleaned utensils properly each time after use but $66.2 \%$ disinfected them. Almost all of respondents kept cool processed products $(93.7 \%)$. 


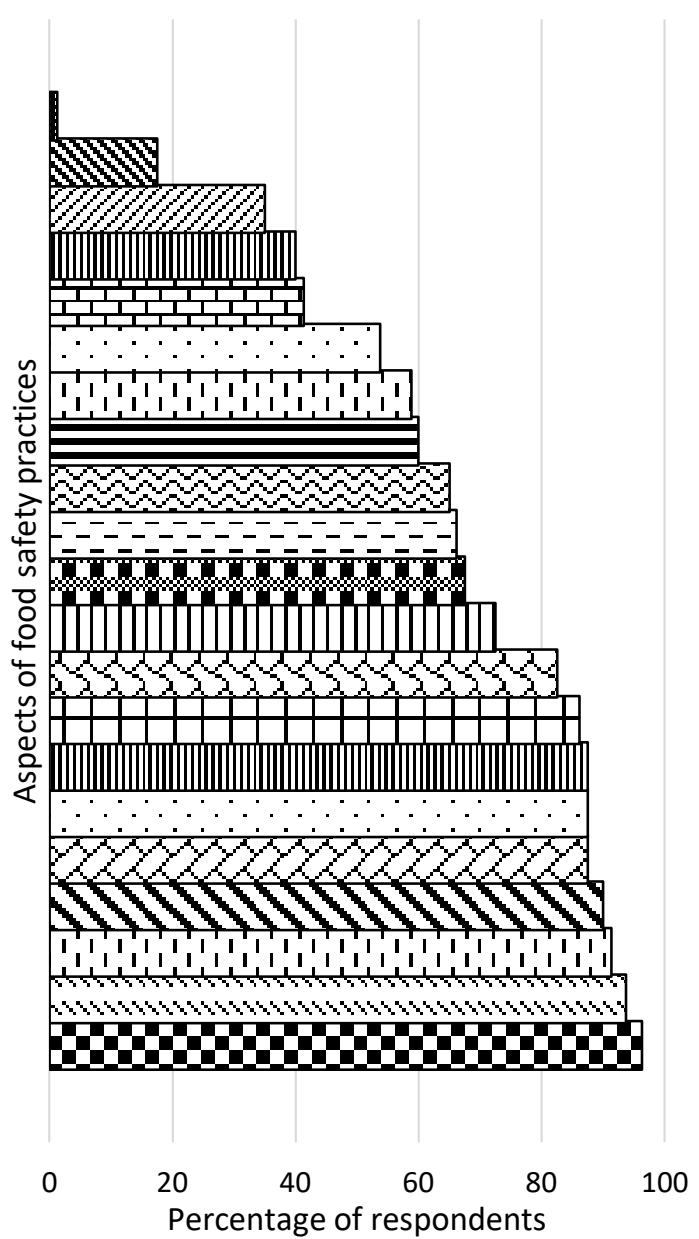

I go for medical health check every six months

I wash my working uniform everyday

$\square$ My equipment is suitable for processing

m The environment around the working room is clean

日My hair are covered while working

$\square$ I sanitize my hands before preparing the food

$\square$ I wear uniform while working

EI handle objects that are not needed for processing during handling

QI wear my Jewelry while working

口I disinfect the work equipment after completing my activity

mI wash my hands using soap before handling the food

DI consume food or beverages inside food processing area

I keep long fingernail

EI handle food with wounds, bruises or injuries on my hands

III I keep colored fingernails

口 I clean up places in contact with food with soap before processing

$\square$ Dirt is removed with a dirty cloth

$\mathbf{Q}$ The utensils are properly cleaned each time after use

口 use separate utensils when preparing my home food and dairies

$\checkmark$ Processed products are kept cool

口I wash my hands after using toilet

Fig 4:-Dairy products handler's practices toward food hygiene and sanitation

\section{Food safety attitude}

Survey consisting of 16 questions was conducted (Table 3). The statement of safe food handling is an important part of the dairy products handler job responsibility was approved by $95.0 \%$ of the respondent. $63.7 \%$ agreed that workers' health should be assessed before hiring, $96.3 \%$ that training of workers in food hygiene is an important part of reducing the risk of food contamination while $88.8 \%$ think that learning more about safe food handling is important to them. Respondents were aware of danger of uncovering hair (95\%), using watches, earrings and rings $(68.8 \%)$, using informal clothes during working $(85 \%)$ or the lack of masks $(80 \%)$. Almost all the respondents were sure that keeping surfaces clean reduces the risk of illness $(98.8 \%)$ and that the same towel cannot be used to clean many places (75\%). $37.5 \%$ of handlers think that the temperature of the pasteurization of the milk cannot be seen directly, $55 \%$ think that it is unsafe to leave dairies out of the refrigerator and $60 \%$ mentioned that it is necessary to periodically check the temperature of the refrigerator to reduce the risk of food contamination. Most of the workers $(92.5 \%)$ were convince that their products are safe for consumers. $81.2 \%$ handlers disagreed producing healthy food depends on financial means only (81.2). Half dairy producters in this study think that pasteurized milk is safer than raw milk.

Table 3:-Attitudes

\begin{tabular}{|l|c|c|}
\hline Statement & $\begin{array}{c}\text { Positive attitude } \\
(\mathbf{\%})\end{array}$ & Mean \pm SD \\
\hline Safe food handling is an important part of my job responsibility & 95 & $1.90 \pm 0.44$ \\
\hline $\begin{array}{l}\text { Training of workers in food hygiene is an important part of reducing the } \\
\text { risk of food contamination }\end{array}$ & 96.3 & $1.93 \pm 0.38$ \\
\hline
\end{tabular}




\begin{tabular}{|c|c|c|}
\hline Workers health should be assessed before hiring & 63.7 & $1.28 \pm 0.68$ \\
\hline Using watches, earrings and rings allows food to be contaminated & 68.8 & $1.38 \pm 0.93$ \\
\hline I think my products are safe for consumers & 92.5 & $1.85 \pm 0.53$ \\
\hline Learning more about safe food handling is important to me & 88.8 & $1.78 \pm 0.64$ \\
\hline Keeping surfaces clean reduces the risk of illness & 98.8 & $2.00 \pm 0.00$ \\
\hline The same towel cannot be used to clean many places & 75 & $1.50 \pm 0.87$ \\
\hline Pasteurized milk is more safe than raw milk & 50 & $1.00 \pm 1.00$ \\
\hline $\begin{array}{l}\text { Wearing working uniform is important to reduce the risk of food } \\
\text { contamination }\end{array}$ & 85 & $1.70 \pm 0.72$ \\
\hline Wearing masks is important to reduce the risk of food contamination & 80 & $1.60 \pm 0.81$ \\
\hline Covering hair is important to reduce the risk of food contamination & 95 & $1.90 \pm 0.44$ \\
\hline I think it is unsafe to leave dairies out of the refrigerator & 55 & $1.10 \pm 1.00$ \\
\hline The temperature of the pasteurization of the milk cannot be seen directly & 37.5 & $0.75 \pm 0.97$ \\
\hline $\begin{array}{l}\text { It is necessary to periodically check the temperature of the refrigerator to } \\
\text { reduce the risk of food contamination }\end{array}$ & 60 & $1.20 \pm 0.99$ \\
\hline Producing healthy food do not depends on financial means only & 81.2 & $1.63 \pm 0.77$ \\
\hline Total & 76.41 & $24.48 \pm 4.15$ \\
\hline
\end{tabular}

Association among knowledge, attitudes and practices of food safety

According to rating scale, summary statistics for total knowledge, attitudes and practices were calculated and mean score for knowledge was 55.28 ( $\mathrm{SD}=10.27$ ) ranging between 32 and 78 scores. Only $10 \%$ of respondents had insufficient knowledge about food safety. Mean score for attitudes was $24.48(\mathrm{SD}=4.15)$ and about $65.5 \%$ had positive attitudes with their 32 as higher score. Mean score for practices was 27.03 ( $\mathrm{SD}=5.70)$, ranging between 10 and 38 points. $40 \%$ of respondents had insufficient food safety practices.

There was positive correlation between knowledge and attitudes $(\mathrm{rs}=0.442, \mathrm{P}<0.000)$, knowledge and practices ( $\mathrm{rs}$ $=0.276, \mathrm{P}=0.013)$ as well as attitudes and practices ( $\mathrm{rs}=0.298, \mathrm{P}=0.007)$. There was also significant association between knowledge and level of education $(\mathrm{rs}=0.27, \mathrm{P}=0.009)$, practices with duration of employment $(\mathrm{rs}=0.40$, $\mathrm{P}<0.001$ ), and knowledge of microbiological food hazards with level of education ( $r s=0.27, \mathrm{P}=0.02)$ (Table 4).

Table 4:-Correlation among knowledge, attitudes and practices level of respondents

\begin{tabular}{|l|l|l|}
\hline Level & Spearman's rho & p \\
\hline Knowledge - Attitudes & $0,442^{* *}$ & 0,000 \\
\hline Knowledge - Practices & $0,276^{* *}$ & 0,013 \\
\hline Attitude - Practices & $0,298^{* *}$ & 0,007 \\
\hline
\end{tabular}

\section{Discussion:-}

The present survey provides an insight to the food safety knowledge, attitudes and practices among dairy products handlers in Ouagadougou, Burkina Faso. The survey shows that the majority dairy products handlers were female. Ba Diao et al. (2002) found that in West Africa, women are at the heart of dairy economy. They directly participate to the production, collection; especially to the processing and the selling dairy products. This dominance of females in Africa is due to their first role in food processing (Dah et al., 2018; Kunadu et al., 2016; Dossou et al., 2015; Egbe et al., 1995).

More than $70 \%$ handlers worked in only one dairy up to now but the maximum time spent in a dairy as an employee, frequently cited is 1 year or less $(41.3 \%)$. The reason of asking handlers about this question was to assure that workers were able to stay a long time in a dairy because strong mobility of workers can be a factor to demotivate managers to invest to their training. A strategy could be worked out in order that workers will be trained at their hiring. The youth of workers can be also a dynamism and innovation factors. Majority of surveyed had primary school level or non-formal education and the most language which is spoken is "mooré". The training plan of these workers should be adapted, by using pictures and local languages. This was noteworthy because workers who have formal education and incomplete basic school education are less likely to properly follow procedures on safe handling of food (Clayton et al., 2002). 
The results indicated a poor knowledge of dairy products handlers about foodborne diseases, symptoms and pathogens. A lot of respondents did not know the risk after ingesting an unsafe dairy product or ignore that typhoid fever and tuberculosis are foodborne illness. Almost all ignore completely foodborne pathogens. Previous research found that food handlers had limited knowledge about pathogens (Sani and Siow, 2014; Al-Shabib et al., 2016). This can affect negatively the quality of dairy products because they may neglect to take necessary steps to control hazards in the food handle (Kunadu et al., 2016). Therefore up to $85 \%$ recognized stomach pain and diarrhea as foodborne illness symptoms. Similar results were obtained from previous study (Woh et al., 2016; Annor and Baiden, 2007). That can due by experience or endogenous knowledge. Hygiene practice is another important component to consider in the reduction of foodborne illnesses (Woh et al., 2016). 92.5\% respondents knew the importance of washing hands before food handling to reduce risk of contamination and more than $80 \%$ knew about risks linked with lack of hands hygiene. However only $67.5 \%$ practiced hand hygiene with soap before processing and $53.8 \%$ with sanitizer. This is troubling because it is a proof of laxity of many workers.

Attitude is also a crucial factor that may influence food safety behavior and practice (Al-Shabib, 2016). Indeed, there is a significant difference between handler's attitude about hair, earrings and rings (95\%) as source of food contamination, and their knowledge or practices (about 40\%). This result was paralleled to the study by AbdulMutalib et al. (2012) where more than $40 \%$ of their respondents wear jewelery while working. This was contradicts with study of Çakiroglu and Uçar (2008) and Al-Shabib et al. (2016), in which they reported respectively that 15.8\% and $24.1 \%$ wore jewelery during production. The similar situation is observed about adequate clothing where $85 \%$ of the workers believe that using informal clothes during working is a risks factors of food poisoning. Unfortunately, up to $50 \%$ wore uniform while working and only $17.5 \%$ washed their working uniform every day. According to Sani and Siow (2014), 93.7\% of their respondents agreed that using adequate clothing reduce risk of food poisoning. The fact that $36.3 \%$ of handlers did not know that it is not only forbidden to handle food in the only case where one is seriously ill and the number of handlers checking health $(1.3 \%)$ has revealed that a lot of dairy products handlers are potential vehicle for transmission of pathogens microorganisms to the product.

The respondents had a positive attitude about keeping surfaces clean to reduce the risk of illness (98.8 \%). Furthermore, in the dairy high percentage of them clean places in contact with dairy products with soap before processing. However $35 \%$ did not know the definition of sanitizing. According to Toh and Birchenough (2000), the lack of knowledge concerning microbiological hazards and the risk of bacterial contamination often leads to inappropriate food handling practice, thus increasing the risk of food poisoning.

The potential sources of cross contamination recognized by handlers were working places and tools (90\%), animals $(67.5 \%)$, raw material $(66.3 \%)$, and ingredients $(41.2 \%)$. Study by Jianu and Golet reported that most of their interviewed in Romania $(87.5 \%)$ indicated pests, poor personal hygiene and improperly sanitized utensils as potential sources of cross contamination. Karaman (2012) reported that the cleaning of protective uniforms and arms of food service staff can be a factor in the spread of foodborne diseases because of poor personal hygiene cross contaminating the product. Knowledge of raw materials and food contact surfaces as possible routes of food contamination is important to prevent cross-contamination or recontamination of food during handling, preparation and storage (Kunadu et al., 2016). Strict food hygiene practices must therefore be followed by the food handlers, to prevent cross-contaminations of foods (Annor and Baiden, 2007).

Globally, respondents had a moderate knowledge about the key role that play time and temperature in dairy products processing (82.5\%). However the majority controlled the temperature of the pasteurization of their raw milk only by eyes observation and do not respect temperature of dairy products storage. Al-Shabib et al. (2016) reported that their participants had the least knowledge about time and temperature control. Shapiro et al.(1999) identified that a lack of food handlers' knowledge of proper storage temperatures could lead to multiplication of bacterial pathogens in food, with resultant outbreaks of illness. Almost all the workers were convince that their final products are safe for consumers. Unfortunately, half of them think raw milk is safe. In this case the dairy producers are able to not pasteurize their raw milk. Such product can transmit some diseases to consumers.

\section{Conclusion:-}

Our survey demonstrates significant gaps in knowledge, attitudes and practices of safe food handling. The findings of this study indicates that food handlers have insufficient levels of knowledge $(55.28 \pm 10.28)$ and practices (27.03 $\pm 5.7)$, and positive attitudes $(24.48 \pm 4.15)$ regarding safe food handling. Dairy products handlers had a limited level of knowledge concerning foodborne diseases, time and temperature control and cross-contamination. We 
recommend targeted educational material to create to keep up with safe food handling practices and new food technologies. Data from this project underline the potential of mandatory on-the-job training of food handlers as required by EU regulation, to significantly improve knowledge scores in Burkina Faso. These gaps could be resolved with risk based training of food handlers in dairies using appropriate training aids to encourage understanding and appreciation of the applications of food safety principles in their day-to-day operations. Training interventions should cover appropriate food protection against contaminations. Habits must be changed to obtain a sustained improvement in food safety practices and this can only be accomplished through continuous and gradual training, monitoring and resource improvement. Techniques employed in this process must also be tailored to accommodate the low education levels of the food handlers.

\section{Acknowledgments:-}

The researchers wish to thank Mister Al-AyattOuédraogo, the president of association of dairy farms and dairy products units in Burkina Faso. The managers of the dairies involved, as well as all food workers who agreed to participate in this study are too appreciate.

\section{References:-}

1. Al-Shabib, N. A., Mosilhey, S. H., \& Husain, F. M. (2016). Cross-sectional study on food safety knowledge, attitude and practices of male food handlers employed in restaurants of King Saud University, Saudi Arabia. Food Control, 59, 212-217.

2. Annor, G. A. \&Baiden, E. A. (2011). Evaluation of Food Hygiene Knowledge Attitudes and Practices of Food Handlers in Food Businesses in Accra, Ghana. Food and Nutrition Sciences, 2, 830-836.

3. Ba Diao, M., Senghor, C.D., Diao, B. \&Thys, E. (2002). Production et transformation du lait en régionagropastorale au Sénégal :cas de la zone périurbaine de Kolda. Revue ÉlevageetMédecinevétérinaire des Pays tropicaux, 55, 221-228.

4. Bagré, T. S. (2015). Evaluation de la contamination des produitslaitiers consommés par des résidusd'antibiotiques, des pathovarsde Escherichia coli et Salmonella enterica au Burkina Faso. Thèse de doctorat unique en sciences biologiquesappliquées. Université de Ouagadougou, 177p.

5. Baş M., Ersun, A. Ş. \&Kıvanç, G. (2006). The evaluation of food hygiene knowledge, attitudes and practices of food handlers in food businesses in Turkey. Food Control, 17, 317-322.

6. Belli, P., Cantafora, A. F. A., Stella, S., Barbieri, S. \&Crimella, C. (2013). Microbiological survey of milk and dairy products from a small scale dairy processing unit in Maroua (Cameroon). Food Control, 32, 366-370.

7. Broutin, C. M., François, F., N'diaye, S. \&Marpeau G. (2002). Analyse de la consommation des produitslaitiers à Kolda". Programme INCO MPE agroalimentaires. Synthèse des résultats. Dakar : GRET- Enda Graf, 21p.

8. Çakiroglu, F. P., \&Uçar, A. (2008). Employees' perception of hygiene in the catering industry in Ankara, Turkey. Food Control, 19, 9-15.

9. Campos, A. K. C., Cardonha, A. M. S., Pinheiro, L. B. G., Ferreira, N. R., Azevedo, P. R. M., \& Stamford, T. L. M. (2009). Assessment of personal hygiene and practices of food handlers in municipal public schools of Natal, Brazil. Food Control, 20, 807-810.

10. Clayton, D. A., Griffith, D. J., Price, P., \& Peters, A. C. (2002). Food handlers' belief and self-reported practices. International Journal of Environmental Health Research, 12, 25-39.

11. Dah, A. P., Guira, F., Tankoano, A., Traoré, K., Sawadogo-Lingani, H. \&Savadogo, A. (2018). Cheese Processing, Marketing, Utilisation and Consumption in Burkina Faso. Current Journal of Applied Science and Technology, 29: 1-12.

12. Dossou, J., Ballogou, V. Y., Dabadé, D. S. \&Dakpo, M. (2015). Analyseéconomique de la production artisanale du chakpalo au Bénin : aspects sociaux et facteursdéterminants de la rentabilitéfinancière de l'activité. Journal of Applied Biosciences, 87, 8065- 8075.

13. Egbe, T. A., Brauman, A., Griffon, D. \&Trèche, S. (1995). La préparationartisanale du gari au Bénin : Aspects technologiques et physico-chimiques. Faculté des Sciences Agronomiques, UniversitéNationale du Bénin, Transformation Alimentaire du Manioc. ORSTOM.

14. Farahat, M. F., El-Shafie, M. M., \&Waly, M. I. (2015). Food safety knowledge and practices among Saudi women. Food Control, 47, 427-435.

15. Flint, J. A., Van Duynhoven, Y. T., Angulo, F. J., DeLong, S. M., Braun, P., Kirk, M., et al. (2005). Estimating the burden of acute gastroenteritis, foodborne disease, and pathogens commonly transmitted by food: an international review. Clinical Infectious Diseases, 41, 698-704. 
16. Gomes-Neves, E., Araújo, A. C., Ramos, E., \& Cardoso, C. F. (2007). Food handling: Comparative analysis of general knowledge and practice in three relevant groups in Portugal. Food Control, 18, 707-712.

17. Grana, H. M., Wetlesena, A., Mutukumirab, A. N., Rukurec, G. \&Narvhusa, J.A. (2003). Occurrence of pathogenic bacteria in raw milk, cultured pasteurised milk and naturally soured milk produced at small-scale dairies in Zimbabwe. Food Control, 14, 8, 539-544.

18. Greig, J. D., Todd, e. c., Bartleson, C. A., \& Michaels, B. S. (2007). Outbreaks where food workers have been implicated in spread of foodborne disease, Part 1, Description of the problem, methods, and agents involved. Journal of Food Protection, 70, 1752-1761.

19. Jevšnik, M., Valentina, H., \&Raspor, P. (2008). Food safety knowledge and practices among food handlers in Slovenia. Food Control, 19, 1107-1118.

20. Jianu, C. \&Golet, I. (2014). Knowledge of food safety and hygiene and personal hygiene practices among meat handlers operating in western Romania. Food Control 42, 214-219.

21. Jørgensen, H. J., Mørk, T. \&Rørvik, L.M. (2005). The occurrence of staphylococcus aureus on a farm with small-scale pProduction of raw milk cheese. Journal of Dairy Science, 88, 3810-3817.

22. Karaman, A. D. (2012). Food safety practices and knowledge among Turkish dairy businesses in different capacities. Food Control, 26, 125-132.

23. Kunadu, P.-H. A., Ofosu, D. B., Aboagye, E. \&Tano-Debrah, K. (2016). Food safety knowledge, attitudes and self-reported practices of food handlers in institutional foodservice in Accra, Ghana. Food Control, 69, 324-330.

24. Mederios, L., Hillers, V., Kendall, P., \& Mason, A. (2001). Evaluation of food safety education for consumers. Journal of Nutrition Education and Behavior, 33, 27-34.

25. Noor-Azira, A.-M., Abdul-Rashid, M.-F., Mustafa, S., Amin-Nordin, S., Hamat, R. A., \& Osman, M. (2012). Knowledge, attitude and practices regarding food hygiene and sanitation of food handlers in Kuala Pilah, Malaysia. Food Control, 27, 289-293.

26. Organisationmondiale de la santé (2014). AntimicrobialResistance: Global Report on Surveillance. 257p.

27. Sahingoz, S. A. \&Sahin, A. (2009). Consumer awareness and food poisoning. Pakistan Journal of Nutrition, 8, 1218-1223.

28. Sani, A. N., \&Siow, O. N. (2014). Knowledge, attitudes and practices of food handlers on food safety in food service operations at the UniversitiKebangsaan Malaysia. Food Control, 37, 210-217.

29. Schneider, M., Kouyaté, H., Fokou, G., Zinsstag, J., Traoré, A., Amadou, M. \&Bonfoh, B. (2007). Dynamiquesd'adaptation des femmes aux transformations des systèmeslaitierspériurbains en Afrique de l'Ouest. ÉlevageetMédecineVétérinaire des Pays tropicaux, 60, 121-131.

30. Sharif, L. \& Al-Malki, T. (2010). Knowledge, attitude and practice of Taif university students on food poisoning. Food Control, 21, 55-60.

31. Tankoano A. (2014). Evaluation de la consommationetanalyse des caractéristiquesphysicochimiques et microbiologiques des produitslaitierslocaux (laitfrais, laitcaillé et yaourt) du Burkina Faso. Diplômed'EtudesApprofondies. Université de Ouagadougou, 92p.

32. Toh, P. S. \&Birchenough, A. (2000). Food safety knowledge and attitudes: culture and environment impact on hawkers in Malaysia. Food Control, 11, 447-452.

33. Toku, B., Ekuklu, G., Berberoğlu, U., Bilge, E., \&Dedeler, H. (2008). Knowledge, attitudes and self-reported practice of food service staff regarding food hygiene in Edrine Turkey. Food Control, 20, 565-568.

34. Woh, P. Y., Thong, K. L., Behnke, J. M., Lewis J. W. \&Zain, S. N. M. (2016). Evaluation of basic knowledge on food safety and food handling practices amongst migrant food handlers in Peninsular Malaysia. Food Control, 70, 64-73. 